\title{
AGRITOURISM ENTREPRENEURS ON THE OTHER SIDE: MOTIVATION AND CHALLENGES
}

\author{
Tan Yi Wei ${ }^{1} \&$ Azreen Rozainee Abdullah² \\ ${ }^{1,2}$ School of Hospitality, Tourism and Culinary Arts, UOW Malaysia KDU Penang University College \\ (tanyiwei21@gmail.com, azreen.rozainee@kdupg.edu.my)
}

\begin{abstract}
Balik Pulau is a uniquely situated landscape on the western side of Penang Island, being both quieter and greener in comparison to Georgetown. It is famous among locals for producing high quality durians. Thus, making it a hotspot for agritourism entrepreneurs. This paper aims to explore the agritourism prospects in Balik Pulau to better understand the motivations and challenges faced by agritourism entrepreneurs in the area. Through in-depth interviews with entrepreneurs, this study has established that the motivation of agricultural entrepreneurs is highly dependent on their goals. Their motivations are also influenced by their individual financial situation, health concerns and eagerness to share and preserve ethnic and agricultural knowledge. This study has identified five challenges faced by agritourism entrepreneurs which are inadequate support from government, private and community sectors, difficulties in employing staff, insufficient infrastructure, seasonal income and encroaching urbanisation. This paper suggests Balik Pulau can be marketed as Penang's agritourism hub and a one-stop centre for durian lovers.
\end{abstract}

KEYWORDS: agritourism, entrepreneur, durian, motivation

\section{PURPOSE AND BACKGROUND}

This paper is focused on Balik Pulau's agritourism entrepreneurs' motivations to start their businesses and the challenges faced while operating in the area. This study also investigates the types of activities offered to tourists from non-durian orchard owners when durians are off-season, and the manner in which orchard owners avoid total income dependency on this seasonal fruit. The main concern area is shortage of land for cultivation and the limited number of agritourism activities in the off-season to meet the growing demand from customers, especially local tourists. The lack of tourist activity is compounded by the fact that several small oil palm plantations, shrimp ponds and mangroves in Balik Pulau have already been converted into housing areas and have given way to urban development which has resulted in the further loss of land available to the agritourism industry.

\section{METHODOLOGY}

Qualitative research methods were used to investigate the circumstances around the agritourism sector in Balik Pulau. Eleven agritourism entrepreneurs were approached but only six were willing to be interviewed. The in-depth interviews were recorded and transcribed verbatim. Purposive sampling was then used to determine the respondents to be targeted. This method was chosen as it took into account the conditions of the person who fulfilled the requirements of the research question, and whether he or she was able to provide the necessary explanations and was inclined to share the information. In order to analyse the data, thematic analysis was practiced in this study. The majority of the respondents were only able to converse in Hokkien language and dialect was then translated using 'Software and Documentation Localization 
(SDL) Trados Studio 2019', an online translation software, so as to ensure the transcripts were correctly translated.

\section{FINDINGS}

The findings of the study revealed that four of the six agritourism entrepreneurs operated homestays on their durian orchards, while the remaining two entrepreneurs operated an animal farm and an apiary. The activities provided at the agritourism sites basically varied according to the landscape of the sites and what motivated the owners to venture into agritourism. The activities included educational tours, hiking, animal riding, honey farming, and cycling which were available all year round to support them financially during off-season.

Their motivations to run the business were also influenced by their individual financial situations, health concerns and eagerness to share and preserve ethnic and agricultural knowledge.

The main challenge faced by most agritourism entrepreneurs was inadequate support from government and private sectors as well as the locals. Due to lack of assistance from these groups, agritourism entrepreneurs were forced to self-fund their operations which meant that the development of their sites was slowed and had to be done in small incremental steps on a very small scale. The second challenge was the difficulties they faced in employing staff due to the hilly landscape in Balik Pulau, remoteness of the area, and the generally poor working conditions.

The third challenge was the lack of infrastructure and poor road conditions in the area. which led to the fourth challenge that was seasonal income. During the durian season, throngs of tourists will visit and stay. However, the off-season sees a sharp decline in the number of visitors and the resulting income, forcing a few of these entrepreneurs to look at other types of activities to attract tourists to the area all-year round.

The last challenge faced by some agritourism entrepreneurs was the encroachment of urbanisation. Developers see Balik Pulau as a potential area for development and offer a fortune for the land. However, offers were turned down by the agritourism business owners due to their strong motivations and their desire to ensure that their legacy will continue and they will be able to preserve the natural beauty of the area.

On the other hand, some of them revealed that urban development has helped to boost their business, making tourists aware and creating easier paths and better roads for tourists to find and reach their business areas. One respondent also said there were negative aspects of urbanisation when new land developers purchased the land in Balik Pulau, they were likely to chop down old wild durian trees, and replace it with famous durian species. In order to enhance plant growth, new land developers are heavily dependent on chemical fertilisers that lead to a loss of soil and water quality.

\section{CONCLUSION}

Balik Pulau offers a unique experience for both local and international tourists. In less than hour, one may travel from the bustling city of Georgetown to the serene and quiet space to enjoy nature and taste durians at their best and most natural. Looking at the remarkable landscape and the different agritourism activities on offer, this research paper suggests that Balik Pulau should be marketed as Penang's agritourism hub and a one-stop center for durian lovers and agritourism. This will not just boost Penang's tourism industry, but also preserve its natural resources. 


\section{CONTRIBUTION/PRACTICAL IMPLICATIONS}

In response to the decline in suitable tracts of agricultural land in Penang, this research paper highlights the importance of motivation and the strong desire among agritourism entrepreneurs in Balik Pulau to stay afloat even though their revenue is seasonal. Their creativity in tackling challenges needs to be credited and their existence helps to preserve the natural resources of Balik Pulau and their enterprise serves as a sustainable form of development in rural areas.

\section{REFERENCES}

Chiang, L., Kim, J., Tang, L., \& Bosselman, R. (2017). Exploring agritoursim entrepreneurship strategies: Antecedents and consequences. Journal of Marketing Management, 5(1), 56-69. https://doi. org/10.15640/jmm.v5n1a6.

Mazlan, Norida \& Juraimi, Abdul Shukor. (2014). Development and challenges of agritourism in Malaysia. Journal of International Society for Southeast Asian Agricultural Sciences, 20(1), 131-138. ISSN 08593132.

Srithong, S., Suthitakan, N., \& Karnjanakit, S. (2019). Participatory community-based agrotourism: A case study of Bangplakod community, Nakhonnayok Province, Thailand. PSAKU International Journal of Interdisciplinary Research, 8(1). https://doi.org/10.2139/ssrn.3398859 